\section{RECOLLECTION OF A PEREGRINE FALCON - PIGEON PURSUIT}

by S. Jordheim, White Bear

Some time ago a Peregrine Falcon was attempting to catch pigeons on the farm here, at first pursuing some around the farmyard, but these soon found refuge in various buildings, while a flock of about 30 took safety, or presumed safety, by climbing to quite a height; this they often do when a Prairie Falcon or Goshawk is around, as these hawks rarely give chase if the pigeons are quite high. But with the Peregrine this meant nothing and he started up after them; as he climbed so did they, and in a short time I lost sight of the pigeons and only with careful observation could I see the falcon, just a mere speck directly above. I was about to give up watching, when I noticed the hawk travelling in a southeast direction, and also becoming a little easier to see, which meant he was coming down. I thought a pigeon must also be coming down but at first couldn't see it, then farther to the southeast and below the hawk I could make out a white speck plunging earthward. A's the race continued, the distance between the two birds narrowed and about half way down, the hawk caught up, but just at the crucial moment the pigeon veered sharply to the side and away. The hawk did not appear to lose any speed; he made a long circle and then plunged down in pursuit, and again, I would guess about 50 feet above the ground, he caught up, and again the pigeon dodged the strike. Levelling off at just a few feet above the ground, it came into the yard with a loud whoosh, and the hawk made no more attempts at it, but with wings set close to its body zoomed upwards to a great height, and not until the force attained by his downward plunge was weakening, did he begin to fly and then to keep going up after the birds that were still up in the clouds. This time I could not keep sight of him, and whether he caught a pigeon, or not, I don't know, but I will never cease to be amazed at the perseverance and energy of this bird.

\section{SECOND REPORT ON SASKATCHEWAN FALCONRY ASSOCIATION BANDING PROGRAM}

\author{
by Glen A. Fox, Saskatoon
}

Our first banding report appeared in 1963 in the Blue Jay, 21:18. Since then our activities have been limited. Most of our members are attending university and this has greatly reduced our man-power. Below is a list of banding carried out since the publication of our first report.

No. banded
since 1963 Date

\begin{tabular}{|c|c|c|c|c|}
\hline Species & 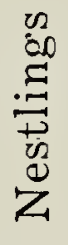 & 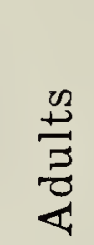 & 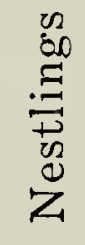 & 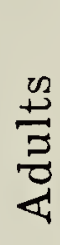 \\
\hline Red-tailed Hawk & 1 & 0 & 30 & 0 \\
\hline $\begin{array}{l}\text { Swainson's Hawk } \\
\text { Ferruginous }\end{array}$ & 0 & 0 & 7 & 1 \\
\hline Hawk & 3 & 0 & 9 & 0 \\
\hline Golden Eagle & 4 & 0 & 5 & 0 \\
\hline Bald Eagle & 2 & 0 & 2 & 0 \\
\hline Turkey Vulture & 2 & 0 & 2 & 0 \\
\hline Marsh Hawk & 3 & 0 & 46 & 0 \\
\hline Peregrine Falcon & 0 & 0 & 0 & 2 \\
\hline $\begin{array}{l}\text { Prairie Falcon } \\
\text { Merlin or Pigeon }\end{array}$ & 2 & 0 & 14 & 1 \\
\hline Hawk & 0 & 0 & 12 & 0 \\
\hline Kestrel or Sparrov & & & & \\
\hline Hawk & 0 & 5 & 5 & 9 \\
\hline Great Horned & & & & \\
\hline Owl & 0 & 1 & 39 & 1 \\
\hline Long-eared Owl & 0 & 0 & 12 & 1 \\
\hline Burrowing Owl & 1 & 6 & 3 & 6 \\
\hline
\end{tabular}

14 Species $\quad \begin{array}{lll}18 & 12 & 186+21 \\ =207 & \text { Raptors }\end{array}$

Grateful acknowledgment of cooperation is made to the Canadian Wildlife Service, Sask. Dept. of Natural Resources, Bernard Haysom, Ralph Carson, Mr. Frank Heidelbauer of Raven Industries Ltd., and $\mathrm{Mr}$. Adam Deutscher. 